\title{
Brazilian Journal \\ of Chemical

\section{COMPARATIVE STUDIES OF THE STABILITY OF FREE AND IMMOBILIZED INULINASE FROM Kluyveromyces marxianus NRRL Y-7571 IN AQUEOUS-ORGANIC SOLUTIONS}

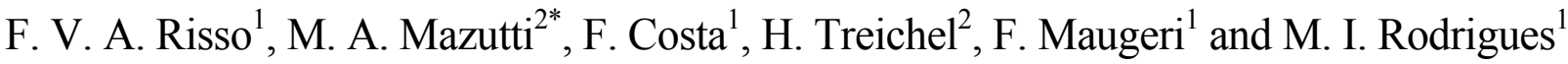 \\ ${ }^{1}$ Department of Food Engineering, Faculty of Food Engineering, \\ Phone: + (55) (54) 3520900, Fax: + (55) (54) 3520-9090, University of Campinas, \\ UNICAMP, P.O Box 6121, CEP 13083-862, Campinas - SP, Brazil. \\ E-mail: bel@fea.unicamp.br \\ ${ }^{2}$ Department of Food Engineering, URI, Campus de Erechim, \\ P. O. Box 743, CEP 99700-000, Erechim - RS, Brazil. \\ *E-mail: mazutti@uricer.edu.br; helen@uricer.edu.br
}

(Submitted: March 25, 2010 ; Revised: May 17, 2010 ; Accepted: June 01, 2010)

\begin{abstract}
Enzymes have been extensively used in organic solvents to catalyze a variety of reactions of biological and industrial significance. In this work, the characteristics of free and immobilized inulinase were investigated in buffered solutions of butyl acetate. The influences of the organic solvent content on the optimal temperature and $\mathrm{pH}$, the stabilities to temperature and $\mathrm{pH}$ and the kinetic parameters were systematically evaluated. The results showed that the organic solvent content had no effect on the optimal $\mathrm{pH}$, either in the free or immobilized inulinase. For the immobilized enzyme, the optimal temperatures ranged from $55^{\circ} \mathrm{C}$ to $60^{\circ} \mathrm{C}$, depending on the content of butyl acetate. At higher butyl acetate content, the stability of the immobilized enzyme increased for both $\mathrm{pH}$ and temperature. The organic solvent showed the tendency to increase the values of the kinetic parameters $\mathrm{K}_{\mathrm{m}}$ and $\mathrm{v}_{\max }$ for both free and immobilized inulinase.

Keywords: Organic solvent; Inulinase; Stability; Kinetic parameters.
\end{abstract}

\section{INTRODUCTION}

Recently, reports have shown that enzymes can be active in organic solvents, showing a good potential in the synthesis of useful products (Rahman et al., 2006). There are numerous advantages of using enzymes in organic solvents or in aqueous solutions containing organic solvents, as compared to water, such as increased solubility of non-polar substrates, a shift in the thermodynamic equilibrium in favor of synthesis over hydrolysis, and the elimination of microbial contamination in the reaction mixtures. Therefore, studies referring to the stabilization and activation of enzymes in the presence of organic solvents are very relevant (Ogino et al., 2007; Klibanov, 2001).
In spite of the fact that enzymatic catalysis in organic solvents presents some technological advantages for a variety of applications, and has already led to some successful commercial processes, enzymes frequently show drastically lower activity in organic solvents than in water. It is believed that the water layer on the molecular surface of enzymes determines their activity. The reduced activity verified in organic media is due to the deactivation effect of organic solvent, unfavorable substrate dissolution, suboptimal $\mathrm{pH}$ and reduced conformational mobility (Wang et al., 2007). An alternative to avoid the direct contact between enzyme and organic solvent is the recovering of the enzyme by immobilization on different inert supports. Besides, the enzyme immobilization offers other advantages over the free

\footnotetext{
*To whom correspondence should be addressed
} 
enzymes, such as the possibility of reuse, continuous operations and higher stability to temperature, $\mathrm{pH}$ and organic solvents (Kumari et al., 2008).

Selection of the correct support for biocatalysis with enzymes is vital, as enzyme efficiency depends largely on the support and its linkage to it. The selected support should have a well-developed internal structure and a large surface area, provided by high porosity. The support should have high affinity (or capacity) for enzymes and a suitable chemical structure (\% hydrophobicity) to provide maximum enzyme activity and enzyme-substrate contact. The support should also be thermally stable, chemically durable, resistant to contamination, and available at a reasonable cost (Gemeiner, 1992). Physical methods, especially adsorption, have an advantage over chemical methods for the immobilization of enzymes onto carriers in that physical adsorption is simple, less expensive and can retain high catalytic activity (Huang et al., 2008; Gao et al., 2009).

Inulinases (2,1- $\beta$-D-fructanohydrolase, E.C. 3.2.1.7) are enzymes that can be used in the production of high fructose syrups (HFS) via the enzymatic hydrolysis of inulin (Silva-Santisteban and Maugeri, 2005) and in the synthesis of fructooligosaccharides (FOS), since the enzyme has significant transfructosylating activity at high sucrose concentrations (Goosen et al., 2008). Recent studies have shown that the use of immobilized inulinase enhances its temperature and $\mathrm{pH}$ stability in buffer solutions (Santos et al., 2007) and allows reuse of the enzyme for several cycles (Singh et al., 2007). Nevertheless, no attempts have been reported in the literature regarding inulinase stability in organic media and only one report could be found of its use for FOS synthesis (Risso et al., 2009).

In this context, the present work investigates the behavior of free and immobilized inulinase in aqueous-organic solutions of butyl acetate, including how the organic solvent content alters the activity, stability, Michaelis constant $\left(\mathrm{k}_{\mathrm{m}}\right)$ and the maximum rate of the sucrose hydrolysis reaction $\left(\mathrm{v}_{\max }\right)$.

\section{MATERIALS AND METHODS}

\section{Microorganism, Medium and Fermentations}

The strain Kluyveromyces marxianus NRRL Y7571 was employed to produce the inulinase, since it belongs to the GRAS (Generally Recognized as Safe) group and is accepted by the U.S. FDA (Food and Drug Administration). The microorganism was grown on YM agar medium containing $\left(\mathrm{g} . \mathrm{L}^{-1}\right)$ : yeast extract (Difco Laboratories) 3.0, malt extract (Difco Laboratories) 3.0, peptone (Difco Laboratories) 5.0, glucose (Synth) 10.0 and agar (Merck) 20.0, and was sub-cultured every three weeks.

Cell production for pre-inoculum was carried out in $50 \mathrm{~mL}$ test tubes with $10 \mathrm{~mL}$ of liquid YM medium. This was inoculated with a loopfull of the stock culture and incubated at $30^{\circ} \mathrm{C}$ for $24 \mathrm{~h}$. Each test tube $(10 \mathrm{~mL})$ with YM medium was transferred to a $500 \mathrm{~mL}$ Erlenmeyer flask with $100 \mathrm{~mL}$ of pre-inoculum medium and incubated in a rotating shaker at $30^{\circ} \mathrm{C}$ and $150 \mathrm{rpm}$ for $24 \mathrm{~h}$. The medium was composed of $\left(\mathrm{g} . \mathrm{L}^{-1}\right)$ : sucrose 20.0, yeast extract 5.0, $\mathrm{K}_{2} \mathrm{HPO}_{4}$ 5.0, $\mathrm{NH}_{4} \mathrm{Cl} 1.5, \mathrm{KCl} 1.15$, and $\mathrm{MgSO}_{4} .7 \mathrm{H}_{2} \mathrm{O} 0.65$.

The fermentation medium was composed as follows $\left(\mathrm{g} . \mathrm{L}^{-1}\right)$ : sucrose 14.0 , yeast extract 10.0 , peptone 20.0 and $\mathrm{K}_{2} \mathrm{HPO}_{4}$ 1.0. The cultures were grown at initial $\mathrm{pH}$ 3.5. Fermentation was carried out by using $10 \%(\mathrm{v} / \mathrm{v})$ of the pre-inoculum medium described above, which corresponds to $1 \times 10^{6} \mathrm{CFU} / \mathrm{mL}$ and incubating at $30^{\circ} \mathrm{C}$ in a rotating shaker (PSYCROTHERM, New Brunswick Scientific, NJ) at $150 \mathrm{rpm}$ for 72 hours (Silva-Santisteban and Maugeri, 2005).

\section{Enzyme Recovery}

The crude fermented broth was centrifuged for 10 minutes at $5000 \mathrm{x} \mathrm{g}$ and $5^{\circ} \mathrm{C}$. To precipitate the inulinase, a $70 \%$ ethanol solution $(\mathrm{v} / \mathrm{v})$ at $4^{\circ} \mathrm{C}$ was pumped into the supernatant at a flow rate of $0.8 \mathrm{~L} \cdot \mathrm{min}^{-1}$. The supernatant was discarded and the precipitate resuspended in $0.1 \mathrm{M}$ sodium acetate buffer, $\mathrm{pH} 4.8$.

\section{Inulinase Immobilization}

The inulinase was immobilized according to the following methodology. A gel solution containing $16.5 \mathrm{~g}$ of distilled water and $0.75 \mathrm{~g}$ of sodium alginate was initially prepared and maintained under brand heating (around $45^{\circ} \mathrm{C}$ ). After complete alginate dissolution, $12.5 \mathrm{~g}$ of sucrose, $5 \mathrm{~mL}$ of solution containing the recovered inulinase, $3.5 \mathrm{~mL}$ of glutaraldehyde and $0.75 \mathrm{~g}$ of activated carbon were added (Risso et al., 2009). After this, the gel solution was pumped into a $0.2 \mathrm{M}$ calcium chloride solution in $0.1 \mathrm{M}$ sodium acetate buffer, $\mathrm{pH} 4.8$, containing $3.5 \%$ of glutaraldehyde at $10^{\circ} \mathrm{C}$ under brand agitation (around $100 \mathrm{rpm}$ ). The immobilized enzymes were maintaining at $4^{\circ} \mathrm{C}$ for $24 \mathrm{~h}$ and, then washed with $0.1 \mathrm{M}$ sodium acetate buffer, $\mathrm{pH} 4.8$. To maintain the spherical conformation, the immobilized enzymes were immersed into a $0.2 \mathrm{M}$ calcium chloride solution in $0.1 \mathrm{M}$ sodium acetate buffer, pH 4.8 (Risso et al., 2009). 
Effect of Organic Solvent on the Characteristics of the Free and Immobilized Inulinase

The effect of the organic solvent on the characteristics of the free and immobilized inulinase was evaluated in terms of the optimal temperature and $\mathrm{pH}$, the $\mathrm{pH}$ and temperature stability, the Michaelis constant $\left(\mathrm{k}_{\mathrm{m}}\right)$ and the maximum rate of the sucrose hydrolysis reaction $\left(\mathrm{v}_{\max }\right)$. The influence of 25,50 and $70(\mathrm{wt} \%)$ of butyl acetate on the above mentioned parameters was investigated. Butyl acetate was chosen since it was the best organic solvent for the synthesis of fructooligosaccharides in another study of our research group (Risso et al., 2009).

To investigate the optimum temperature, assays were carried out at different temperatures ranging from 30 to $70^{\circ} \mathrm{C}$. To determine the optimum $\mathrm{pH}$, assays were carried out using sodium acetate buffers at different $\mathrm{pH}$ values ( 3.6 to 5.6 ) at $50^{\circ} \mathrm{C}$, and the activity measured after 10 minutes of reaction. The reaction time was defined on the basis of a kinetic study that showed that, after 10 minutes, the enzyme activity is at the steady-state (data not shown).

To determine the thermal stability, free and immobilized inulinase in $0.1 \mathrm{M}$ sodium acetate buffer, $\mathrm{pH} 4.8$, were incubated at 50.0, 52.5, 57.5, $60.0,62.5$ and $65.0^{\circ} \mathrm{C}$ in a temperature controlled water bath. The half-life of the enzyme for each temperature was experimentally determined and used to compute the activation energy for enzyme deactivation according to the Arrhenius Equation:

$\mathrm{k}=\mathrm{k}_{0} \cdot \exp \left(\frac{-\mathrm{Ed}}{\mathrm{R} \cdot \mathrm{T}}\right)$

where $\mathrm{k}$ is the inactivation constant, $\mathrm{k}_{0}$ is the preexponential factor, Ed is the activation energy for enzyme deactivation, $\mathrm{R}$ is the ideal gas constant (8.314 J.mol ${ }^{-1} \cdot \mathrm{K}^{-1}$ ) and $\mathrm{T}$ is the temperature in $\mathrm{K}$. The inactivation constant, $\mathrm{k}$, is defined according the following equation:

$\mathrm{k}=\frac{0.693}{\mathrm{t}_{1 / 2}}$

where $t_{1 / 2}$ is the half-life of the enzyme. Substituting (2) in (1) the resulting linear expression is given by:

$\ln \left(\frac{1}{\mathrm{t}_{1 / 2}}\right)=\ln \left(\frac{\mathrm{k}_{0}}{0.693}\right)-\frac{\mathrm{Ea}}{\mathrm{R}} \cdot \frac{1}{\mathrm{~T}}=\mathrm{c}-\frac{\mathrm{Ea}}{\mathrm{R}} \cdot \frac{1}{\mathrm{~T}}$
Slopes were calculated by linear regression assuming first-order deactivation.

The influence of $\mathrm{pH}$ on the stability of the free and immobilized inulinase was determined by incubating the enzymes in $0.1 \mathrm{M}$ sodium acetate buffers at $\mathrm{pH} 4.0,4.4,4.8,5.2$ and 5.6 at a temperature of $50^{\circ} \mathrm{C}$. Residual activity was measured at different intervals of time in terms of relative activity and the experimental half-life of the enzyme determined at each $\mathrm{pH}$.

To determine the kinetic parameters, enzyme assays were carried out using $1.0 \mathrm{~mL}$ of extract or, in the case of the immobilized enzyme, particles in $0.1 \mathrm{M}$ sodium acetate buffer at $\mathrm{pH} 4.8$ and $50^{\circ} \mathrm{C}$ with sucrose concentrations increasing from 0.5 to $35 \mathrm{~g} . \mathrm{L}^{-1}$. The $K_{m}$ and $V_{m}$ values of the Michaelis-Menten equation:

$\mathrm{v}=\frac{\mathrm{v}_{\max } \cdot \mathrm{S}}{\mathrm{k}_{\mathrm{m}}+\mathrm{S}}$

where $\mathrm{v}$ is the reaction rate, $\mathrm{v}_{\max }$ is the maximum reaction rate, $\mathrm{S}$ is the substrate concentration and $\mathrm{k}_{\mathrm{m}}$ is the saturation constant, were determined from Lineweaver-Burk plots, according to the following linearized form of the equation:

$\frac{1}{\mathrm{v}}=\frac{\mathrm{k}_{\mathrm{m}}}{\mathrm{v}_{\max }} \cdot \frac{1}{\mathrm{~S}}+\frac{1}{\mathrm{v}_{\max }}$

The $\mathrm{v}_{\max }$ and $\mathrm{k}_{\mathrm{m}}$ are obtained by plotting $1 / \mathrm{v}$ versus $1 / \mathrm{S}$, which yield straight lines with an intercept on the $\mathrm{y}$-axis of $1 / \mathrm{v}_{\max }$ and a slope of $\mathrm{k}_{\mathrm{m}} / \mathrm{v}_{\max }$.

\section{Inulinase Assay}

The inulinase activity was measured by incubating $1.0 \mathrm{~mL}$ of appropriately diluted enzyme source, or $1 \mathrm{~mL}$ of particles in the case of the immobilized enzyme, with $9.0 \mathrm{~mL}$ of $2 \%(\mathrm{w} / \mathrm{v})$ sucrose solution at $50^{\circ} \mathrm{C}$ in sodium acetate buffer (0.1 mol. $\left.\mathrm{L}^{-1}, \mathrm{pH} 4.8\right)$ for 10 minutes. In the latter case, the volume of the particles was measured by considering the equivalent volume of water displaced in a graduated tube (Santos et al., 2007). The reducing sugars released were measured using the 3,5-dinitrosalicylic acid method (Miller, 1959) and one unit of inulinase activity was defined as the amount of enzyme releasing $1 \mu \mathrm{mol}$ of reducing sugar as glucose per minute, under the standard assay conditions. 
All the experiments were carried out in triplicate with standard deviations lower than 5\%.

\section{RESULTS AND DISCUSSION}

\section{Optimal Temperature and $\mathrm{pH}$}

Figure 1 presents the results of inulinase activity in terms of the $\mathrm{pH}$ and the temperature for free and immobilized inulinase at 25,50 and $70 \mathrm{wt} \%$ of butyl acetate. Free inulinase presented an optimal temperature of $50^{\circ} \mathrm{C}$ (Figure 1(a)) and $\mathrm{pH}$ of 4.8 (Figure 1(c)), at all contents of organic solvent (OS). Using $50 \mathrm{wt} \%$ of butyl acetate, free inulinase showed the highest catalytic power, since the activity was higher than at 25 and $70 \mathrm{wt} \%$ for both $\mathrm{pH}$ and temperature. Mazutti et al. (2007) reported an optimal temperature and $\mathrm{pH}$ of $55.0^{\circ} \mathrm{C}$ and 5.0 , respectively, for free inulinase obtained by solid- state fermentation using the same strain in sodium acetate buffer.

Immobilized inulinase showed an optimal temperature of $55^{\circ} \mathrm{C}$ in 25 and $70 \mathrm{wt} \%$ of OS and of $60^{\circ} \mathrm{C}$ in $50 \mathrm{wt} \%$ OS (Figure 1(b)), and the optimal pH was 4.8 for all the OS contents (Figure 1(d)). The $\mathrm{pH}$ and temperature showed similar results of optimum values in terms of inulinase activity for all the butyl acetate contents and these activities were higher than those obtained for the enzyme in its free form. This was expected since immobilization contributes to a more efficient stabilization of the enzyme solution. In terms of the effect of temperature on the enzyme activity, the butyl acetate content slightly affected the optimal temperature. Catana et al. (2005) found an optimal temperature in the range from $50^{\circ} \mathrm{C}-60^{\circ} \mathrm{C}$ and optimal $\mathrm{pH}$ of 4.0 for the immobilized enzyme and Cazetta et al. (2005) reported an optimum temperature of $60^{\circ} \mathrm{C}$ for immobilized inulinase from Kluyveromyces marxianus ATCC 16045.

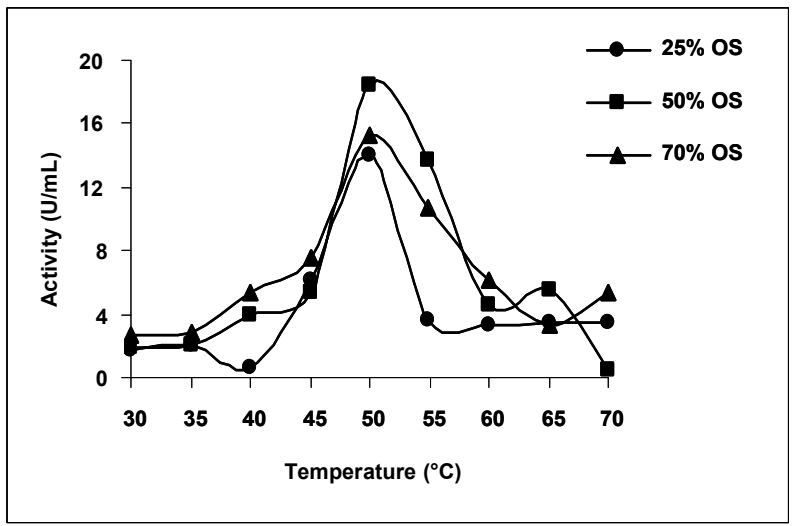

(a) Free Inulinase

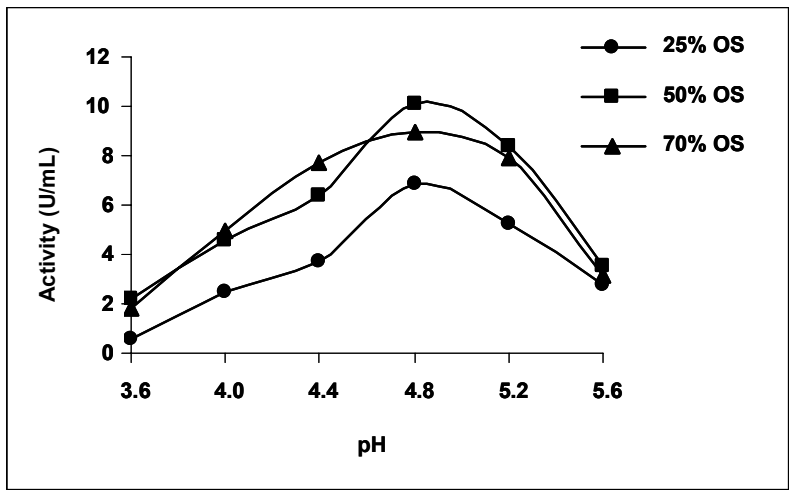

(c) Free Inulinase

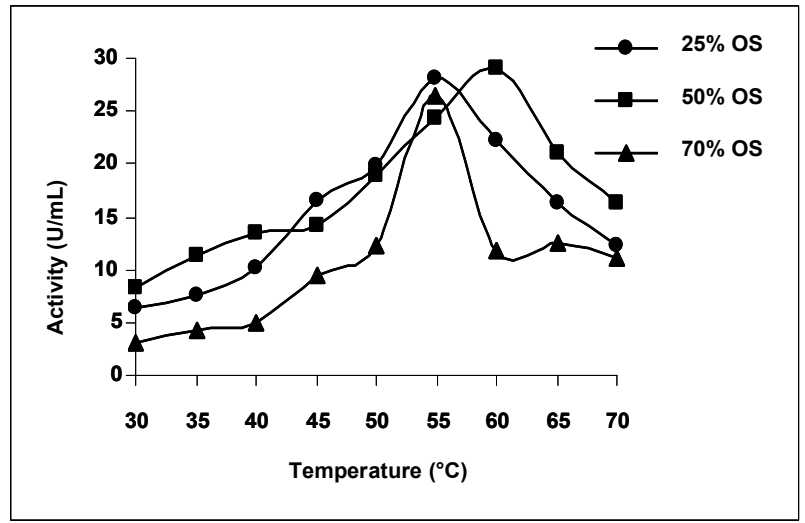

(b) Immobilized Inulinase

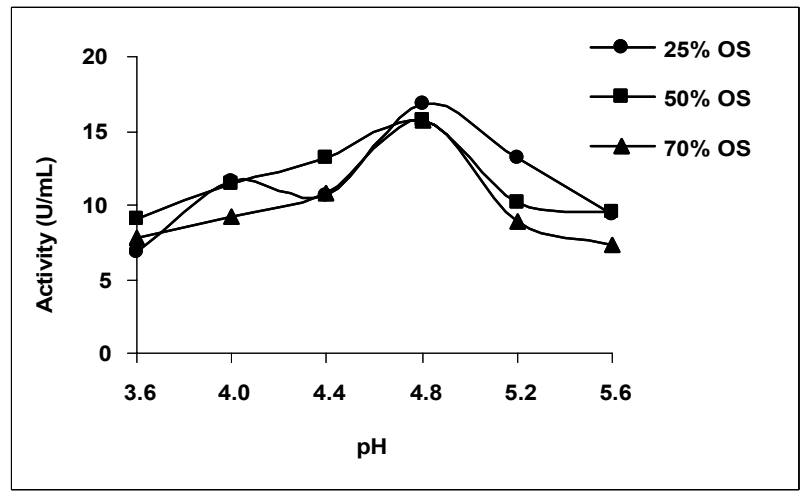

(d) Immobilized Inulinase

Figure 1: Influence of temperature (a) and (b) and $\mathrm{pH}$ (c) and (d) on inulinase activity after 10 minutes of reaction at the three organic solvent (OS) contents for free and immobilized enzyme, respectively. 
The data presented in Figures 1(a) and 1(b) were used to estimate the activation energy for the process using an Arrhenius plot (Eq. 3), which yields a straight line with a slope of $\mathrm{Ea} / \mathrm{R}$. Considering the enzyme in the free form, the activation energies determined were 104.9, 54.3 and $56.8 \mathrm{~kJ} \cdot \mathrm{mol}^{-1}$ for 25,50 and $70 \mathrm{wt} \%$ of butyl acetate, respectively. For the immobilized enzyme, the values were $51.2,34.0$ and $71.1 \mathrm{~kJ}^{-\mathrm{mol}^{-1}}$ for 25 , 50 and $70 \mathrm{wt} \%$ of butyl acetate, respectively. These results show that the immobilization and the organic solvent concentration affect the catalytic power of the inulinase. The values obtained here are considerably different from those reported by Ettalibi and Baratti (2001) for free $\left(29.4 \mathrm{~kJ} \cdot \mathrm{mol}^{-1}\right)$ and immobilized $\left(26 \mathrm{~kJ} . \mathrm{mol}^{-1}\right)$ inulinase from A. niger in sodium acetate buffer, but agree with those reported by Santos et al. (2007) for free (45.9 $\left.\mathrm{kJ} . \mathrm{mol}^{-1}\right)$ and immobilized $\left(42.0 \mathrm{~kJ} . \mathrm{mol}^{-1}\right)$ inulinase from $K$. marxianus ATCC 16045 in a citrate buffer medium. There are no data regarding the activation energies for the inulinase obtained from the strain K. marxianus NRRL Y-7571.

\section{Effect of Temperature on Inulinase Stability}

Figure 2 presents the kinetic profiles in terms of residual activity obtained at the different temperatures evaluated for free and immobilized enzyme for all the OS contents. Table 1 summarizes the data for the experimental half-lives for the free and immobilized inulinase at the three butyl acetate concentrations evaluated. The highest stability was obtained at $50^{\circ} \mathrm{C}$ for both the free and immobilized inulinase. As expected, the immobilized enzyme was more stable, mainly in the medium containing 50 and $70 \mathrm{wt} \%$ of butyl acetate. For temperatures above $50^{\circ} \mathrm{C}$, there was a reduction of about $90 \%$ in the halflife for both enzymes, independent of the organic solvent (OS) content used. The half-life values obtained in the present work for the free enzyme at $50^{\circ} \mathrm{C}$ ranged from 540 to 908 minutes. These values are quite different from those reported in the literature for the free enzyme in aqueous systems. Mazutti et al. (2007) reported half-lives of 2224.0 and 322.0 minutes at $50^{\circ} \mathrm{C}$ and $55^{\circ} \mathrm{C}$, respectively, and Treichel et al. (2009) found half-lives of 4158.0 and $594.0 \mathrm{~min}$ at $50^{\circ} \mathrm{C}$ and $52.5^{\circ} \mathrm{C}$, respectively, for the free inulinase from K. marxianus NRRL Y-7571 in sodium acetate buffer. These results suggest that the use of an organic solvent in the reaction medium decreases the free enzyme stability, as previously reported (Klibanov, 2001).
The experimental half-life values presented in Table 1 were used to calculate the inactivation rate constant $\left(\mathrm{k}_{\mathrm{d}}\right)$. As presented in Table 1, the Ed value for both the free and immobilized inulinase increased with the butyl acetate concentration. Since Ed values represents the energy necessary to start the inactivation reaction and this value was lower for the immobilized enzyme than that for the free enzyme, one can conclude that the immobilized enzyme was less stable than the free enzyme when using this immobilization method (Santos et al., 2007). These results are similar to those reported by Mazutti et al. (2007) (343.9 $\mathrm{kJ} \cdot \mathrm{mol}^{-1}$ ) and lower than those of Treichel et al. (2009) $\left(527 \mathrm{~kJ} \cdot \mathrm{mol}^{-1}\right)$ for free inulinase.

The temperature exerted two antagonistic effects on the enzymatic process. An initial activating effect up to the optimal temperature, followed by an undesirable inactivation effects, was observed. From the industrial point of view, it is interesting that the optimal and the most stable temperatures are the same, since this would imply a high reaction rate and low cost for enzymes. This aspect was verified with the free enzyme, since at $50^{\circ} \mathrm{C}$ the enzyme showed a half-life of 908 minutes at $70 \mathrm{wt} \%$ of OS. However, for the immobilized inulinase, there was a strong inactivation at the optimal temperature for hydrolysis, since the immobilized enzyme showed very low half-life values at temperatures above $52.5^{\circ} \mathrm{C}$.

\section{Effect of pH on Inulinase Stability}

Figure 3 presents the kinetic profiles in terms of residual activity obtained at the pHs evaluated for free and immobilized enzyme for all the OS contents. Table 2 presents the effects of $\mathrm{pH}$ on the experimental half-life for the free and immobilized enzymes. The different organic solvent concentrations resulted in different enzyme stabilities. At $25 \mathrm{wt} \%$ of butyl acetate, inulinase presented more stability at $\mathrm{pH}$ values of 4.4 and 4.0 for the free and immobilized forms, respectively, with half-lives above 1440 minutes. At other $\mathrm{pH}$ values, the free form was more stable than the immobilized form. Using $50 \mathrm{wt} \%$ of butyl acetate, the immobilized inulinase was more stable than the free form over the whole range of $\mathrm{pH}$ values investigated and at $\mathrm{pH} 4.0$ and 4.4 it showed half-life values above 1440 minutes. On the other hand, at $70 \mathrm{wt} \%$ of butyl acetate, the free and immobilized forms were stable at $\mathrm{pH} 4.0$ with halflife values above 1440 minutes. The immobilized inulinase showed good stability over the whole range investigated, while the free form was only stable at $\mathrm{pH} 4.0$. 


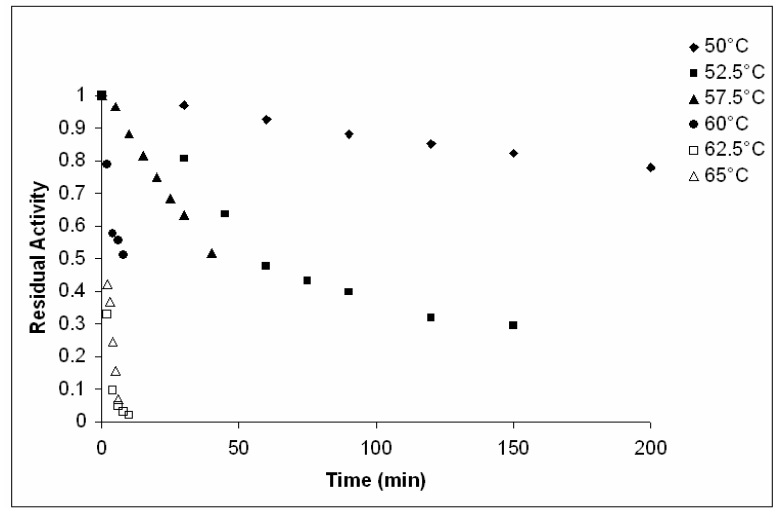

(a) Free $-25 \%$ OS

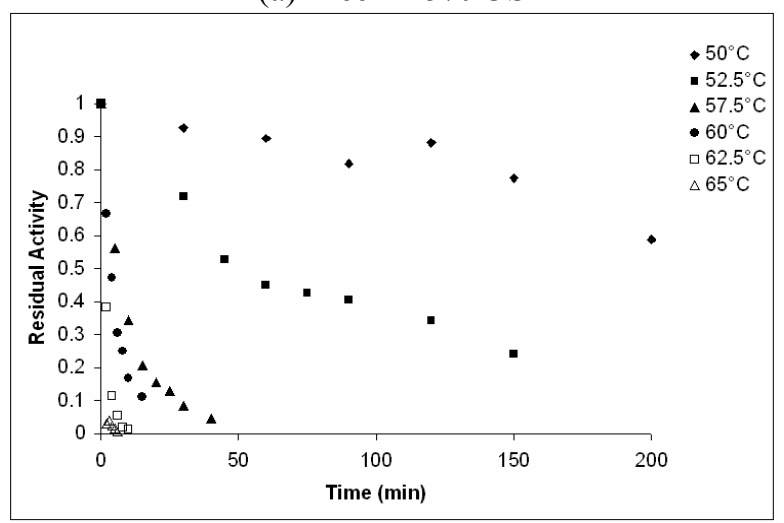

(c) Free $-70 \%$ OS

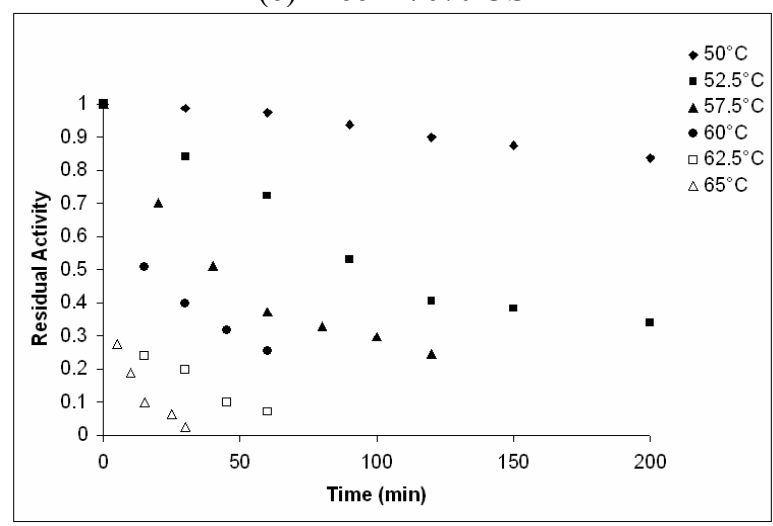

(e) Immobilized - 50\% OS

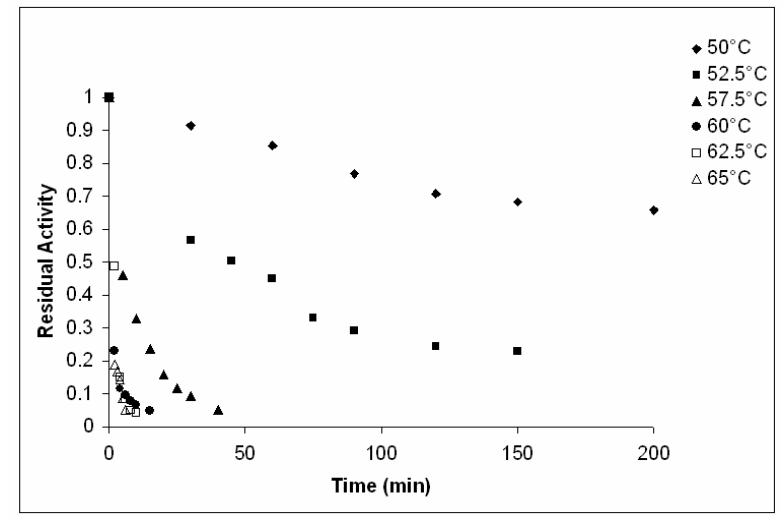

(b) Free $-50 \%$ OS

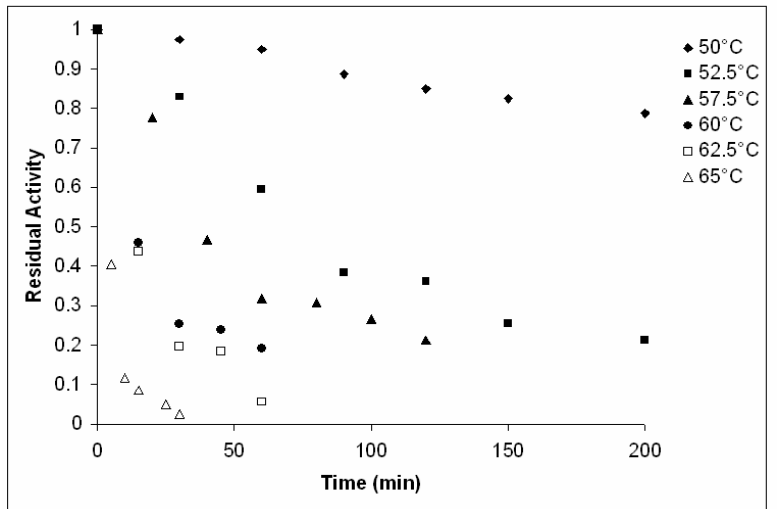

(d) Immobilized $-25 \%$ OS

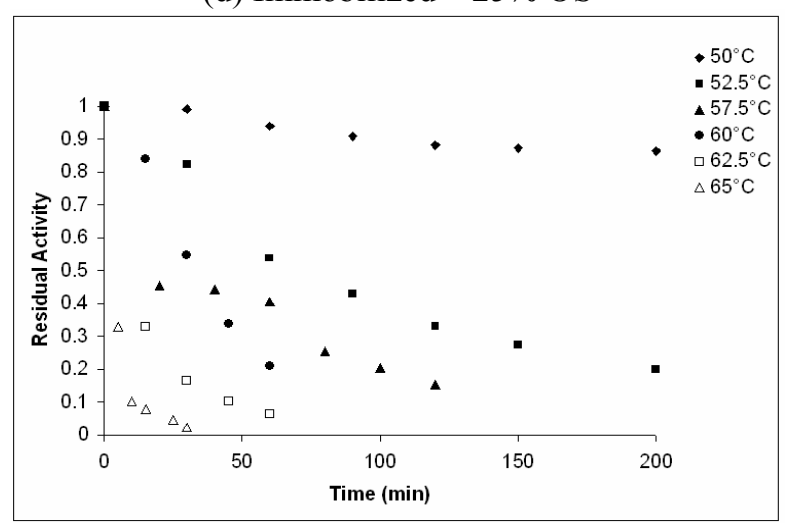

(f) Immobilized - 70\% OS

Figure 2: Effect of temperature on enzyme stability at 25, 50 and 70\% of OS content for free (a), (b) and (c) and immobilized (d), (e) and (f) forms.

Table 1: Effect of temperature on the half-life in minutes for the free and immobilized inulinase

\begin{tabular}{|c|c|c|c|c|c|c|}
\hline \multirow{2}{*}{$\begin{array}{c}\text { Temperature } \\
\left({ }^{\circ} \mathrm{C}\right)\end{array}$} & \multicolumn{2}{|c|}{$25 \mathrm{wt} \% \mathrm{OS}$} & \multicolumn{2}{|c|}{$50 \mathrm{wt} \%$ OS } & \multicolumn{2}{|c|}{70 wt\% OS } \\
\hline & Free & Immobilized & Free & Immobilized & Free & Immobilized \\
\hline 50.0 & 540.0 & 912.0 & 640.0 & 1251.8 & 908.0 & 1288.3 \\
\hline 52.5 & 49.5 & 72.9 & 46.1 & 100.0 & 54.3 & 78.8 \\
\hline 57.5 & 45.0 & 37.6 & 4.6 & 42.4 & 6.7 & 36.0 \\
\hline 60.0 & 8.7 & 13.9 & 1.3 & 16.1 & 3.9 & 18.4 \\
\hline 62.5 & 1.5 & 13.3 & 1.9 & 9.9 & 1.6 & 11.2 \\
\hline 65.0 & 1.7 & 4.2 & 1.2 & 3.4 & 1.0 & 3.7 \\
\hline Ed $(\mathrm{kJ} / \mathrm{mol})$ & 348.5 & 314.9 & 393.3 & 356.3 & 430.4 & 352.2 \\
\hline
\end{tabular}

Ed: Activation energy for enzyme deactivation 


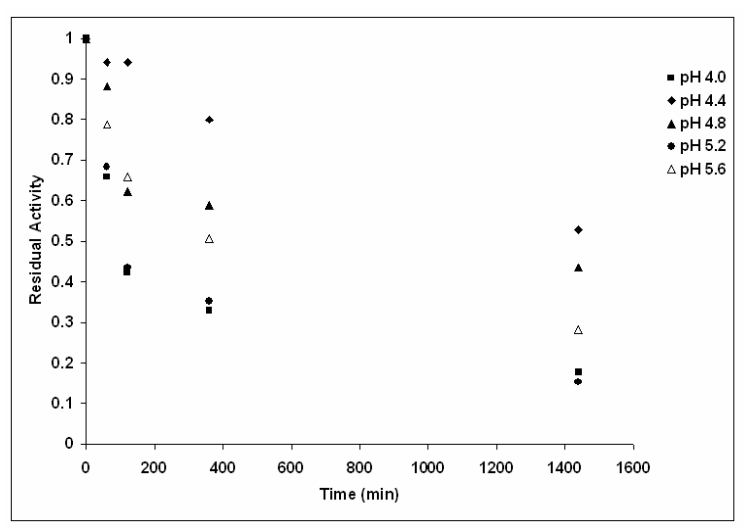

(a) Free $-25 \%$ OS

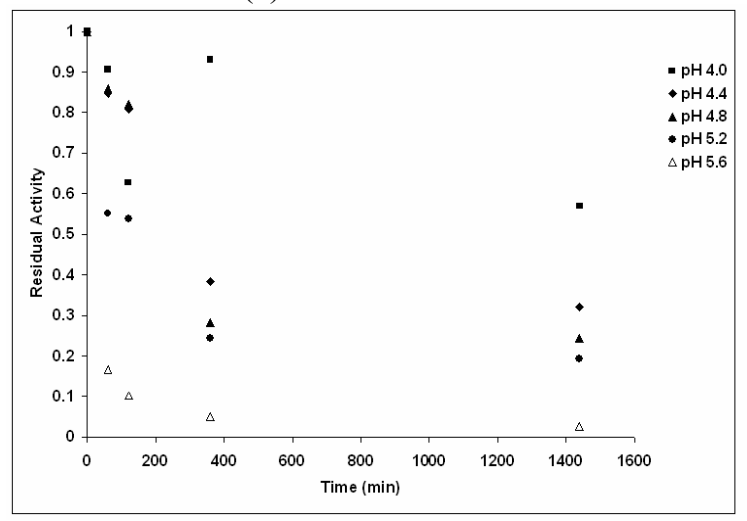

(c) Free $-70 \%$ OS

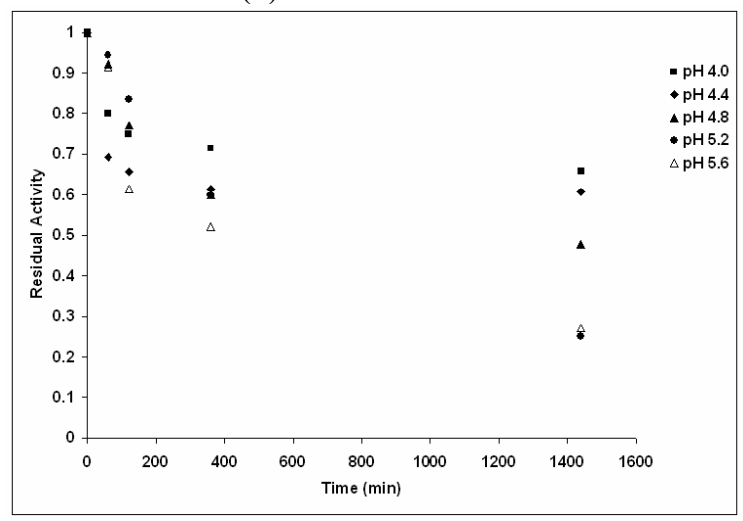

(e) Immobilized $-50 \%$ OS

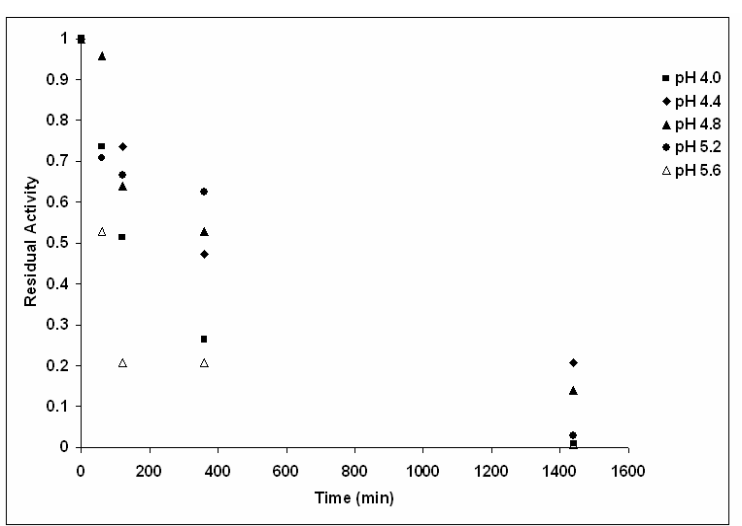

(b) Free $-50 \%$ OS

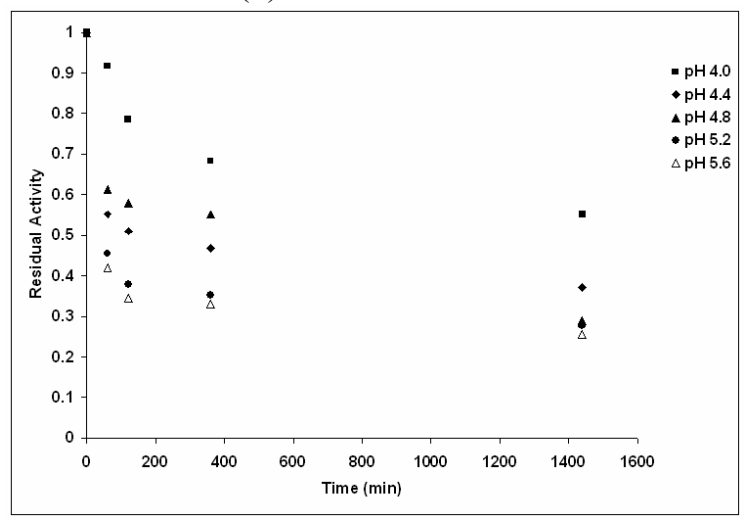

(d) Immobilized $-25 \%$ OS

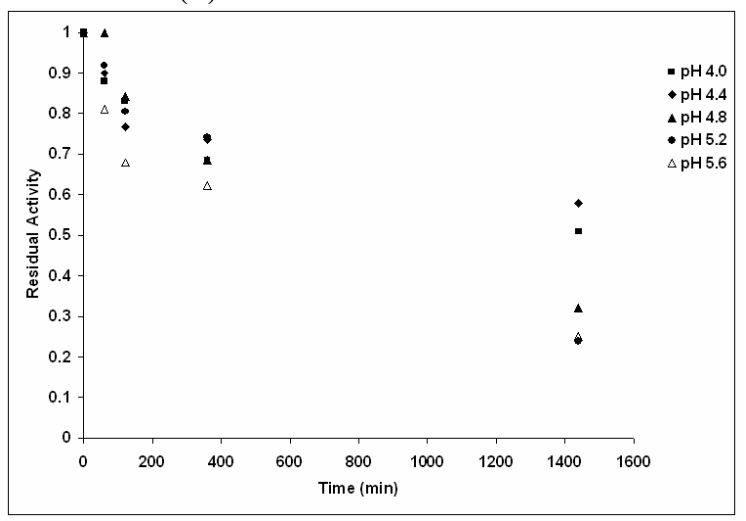

(f) Immobilized - 70\% OS

Figure 3: Effect of $\mathrm{pH}$ on enzyme stability at 25, 50 and $70 \%$ of OS content for free (a), (b) and (c) and immobilized (d), (e) and (f) forms.

Table 2: Effect of $\mathrm{pH}$ on the half-life in minutes for the free and immobilized inulinase

\begin{tabular}{|c|c|c|c|c|c|c|}
\hline \multirow{2}{*}{ pH } & \multicolumn{2}{|c|}{$25 w t \%$ OS } & \multicolumn{2}{|c|}{50 wt\% OS } & \multicolumn{2}{|c|}{$70 \mathrm{wt} \%$ OS } \\
\hline & Free & Immobilized & Free & Immobilized & Free & Immobilized \\
\hline 4.0 & 100.6 & $>1440.0$ & 133.4 & $>1440.0$ & $>1440.0$ & $>1440.0$ \\
\hline 4.4 & $>1440.0$ & 269.3 & 334.5 & $>1440.0$ & 294.8 & $>1440.0$ \\
\hline 4.8 & 981.2 & 571.0 & 437.7 & 1252.6 & 262.8 & 910.4 \\
\hline 5.2 & 104.2 & 55.0 & 586.1 & 668.6 & 151.0 & 879.6 \\
\hline 5.6 & 388.9 & 51.8 & 65.3 & 450.7 & 36.0 & 718.1 \\
\hline
\end{tabular}


The results presented in Table 2 show that the immobilized enzyme stability increased with the organic solvent concentration at all $\mathrm{pH}$ values tested. This fact indicates that the immobilization procedure that was carried out seems to be efficient in preventing enzyme inactivation. However, for the free enzyme, a reduction in stability occurred when the OS concentration increased, except at the $\mathrm{pH}$ values of 4.0 and 5.2, at which the enzyme was more stable using 70 and $50 \mathrm{wt} \%$ of OS, respectively.

The enzyme stabilities obtained in this work were lower than that reported in the literature for the inulinase obtained from Kluyveromyces marxianus NRRL Y-7571 in aqueous systems. Mazutti et al. (2007) reported that the free inulinase in sodium acetate buffer retained $67 \%$ of its initial activity after 3300.0 minutes of reaction at $\mathrm{pH}$ values of 4.5 and 4.8 and Treichel et al. (2009) found a half-life of $4920.0 \mathrm{~min}$ at $\mathrm{pH}$ 4.4. The temperature used in all these experiments was $50^{\circ} \mathrm{C}$. These differences in the enzyme stabilities can be related to the purification procedure, since this can change the enzyme characteristics. Mazutti et al. (2007) studied a crude broth containing the inulinase to determine the enzyme characteristics. On the other hand,

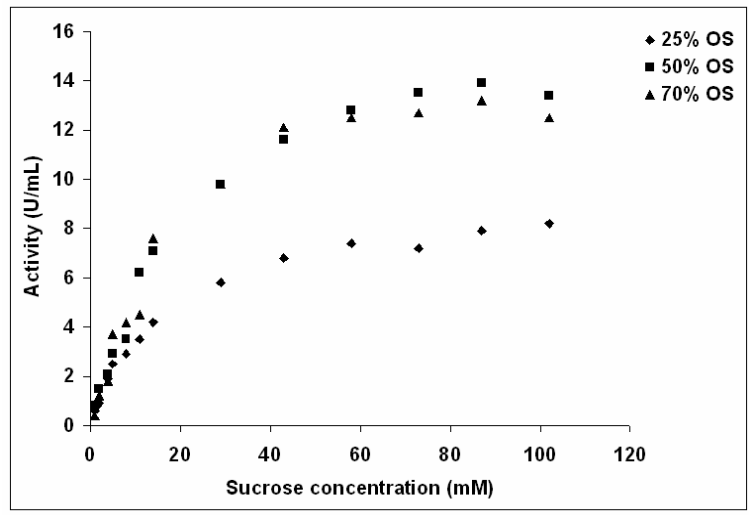

(a)

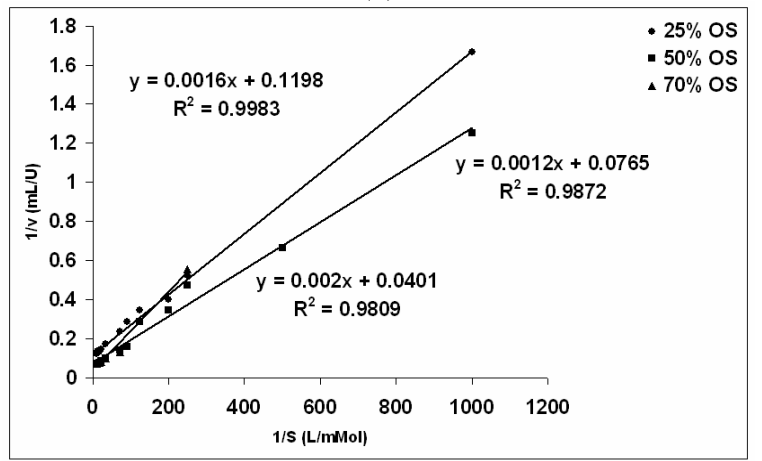

(c)
Treichel et al. (2009) evaluated the enzyme after a treatment in an expanded bed of Streamline Sp resin. Both procedures were different from that used in the present work.

\section{Kinetic Parameters for the Free and Immobilized Inulinase}

Figures 4(a) and 4(c) present the saturation curves of the enzymatic reaction for free and immobilized enzyme, respectively, showing the relation between the substrate (sucrose) concentration and the reaction rate for all the OS contents. The data of Figures 4(a) and 4(c) were used to determine the maximum reaction rate, $\mathrm{V}_{\max }$, and the Michaelis-Menten constant, $\mathrm{k}_{\mathrm{m}}$, for free and immobilized enzyme from the Lineweaver-Burk plots shown in Figures 4(b) and $4 \mathrm{~d}$, respectively. Table 3 summarizes the results obtained for the influence of the butyl acetate content on the kinetic constants $\mathrm{v}_{\max }$ and $\mathrm{k}_{\mathrm{m}}$ for the free and immobilized inulinase. For both the free and immobilized enzymes, the values of $\mathrm{v}_{\max }$ increased with the OS concentration. Considering the absolute values, the immobilized enzyme showed higher values for all the OS concentrations.

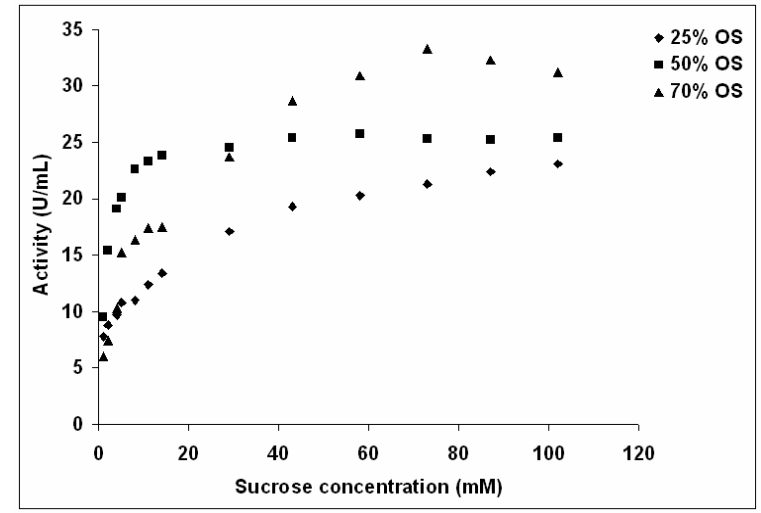

(b)

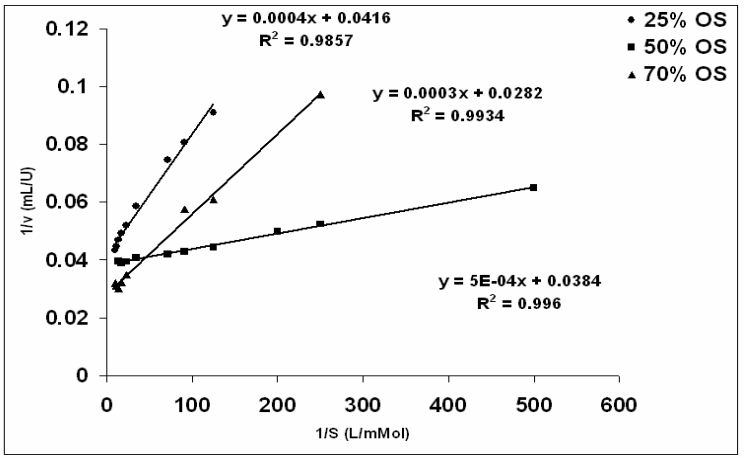

(d)

Figure 4: Saturation curves and Lineweaver-Burk plots for free (a) and (c) and immobilized (b) and (d) inulinase at different organic solvent contents. 
Table 3: The kinetic parameters for the free and immobilized inulinase at the three organic solvent (OS) contents

\begin{tabular}{|l|r|r|r|r|r|r|}
\hline \multirow{2}{*}{ OS (wt\%) } & \multicolumn{3}{|c|}{$\mathbf{v}_{\max }\left(\mathbf{U}_{\mathbf{m}} \mathbf{m L}^{-\mathbf{1}}\right)$} & \multicolumn{3}{|c|}{$\mathbf{k}_{\mathbf{m}}(\mathbf{m M})$} \\
\cline { 2 - 7 } & $\mathbf{2 5}$ & $\mathbf{5 0}$ & $\mathbf{7 0}$ & $\mathbf{2 5}$ & $\mathbf{5 0}$ & $\mathbf{7 0}$ \\
\hline Free & 8.3 & 13.1 & 24.9 & 13.3 & 15.7 & 49.9 \\
Immobilized & 24.1 & 26.2 & 35.5 & 9.6 & 11.3 & 10.6 \\
\hline
\end{tabular}

On the other hand, the affinity of the enzyme for the substrate seems to decrease for free inulinase since the $\mathrm{k}_{\mathrm{m}}$ values increased. For immobilized inulinase, the $\mathrm{k}_{\mathrm{m}}$ values were lower than for the free enzyme. These results indicate that the higher values of $\mathrm{V}_{\max }$ obtained for the immobilized enzyme could be the consequence of the higher affinity of the enzyme for the substrate than that verified for the free enzyme.

In addition, one can observe some differences in the $\mathrm{k}_{\mathrm{m}}$ and $\mathrm{v}_{\max }$ values between the free and immobilized inulinase and for the three butyl acetate contents. These values are in agreement with previous work carried out by Mazutti et al. (2007) and Treichel et al. (2009), who evaluated the free enzyme in $0.1 \mathrm{M}$ sodium acetate buffer at $\mathrm{pH} 4.8$. Mazutti et al. (2007) found 17.2 U.mL ${ }^{-1}$ for $\mathrm{v}_{\max }$ and $7.1 \mathrm{mM}$ for $\mathrm{k}_{\mathrm{m}}$, while Treichel et al. (2009) reported 10.7 U.mL ${ }^{-1}$ and $13.0 \mathrm{mM}$ for $\mathrm{v}_{\max }$ and $\mathrm{k}_{\mathrm{m}}$, respectively.

\section{CONCLUSIONS}

The results show that the immobilization improved the enzyme stability at the different $\mathrm{pH}$ values, especially at high organic solvent contents. The immobilized enzyme was less stable at the different temperatures when compared to the free enzyme, since lower inactivation energies were obtained using the enzyme at this form. However, the enzyme was less stable towards both $\mathrm{pH}$ and temperature in the presence of the organic solvent, since the half-lives obtained in this study were lower than those reported in the literature for inulinase in aqueous systems. The fact that the enzyme presents hydrolytic activity in the presence of OS indicates that further studies aimed at using inulinase in an organic solvent to synthesize fructooligosaccharides from sucrose are indeed warranted.

\section{REFERENCES}

Catana, R., Ferreira, B. S., Cabral, J. M. S. and Fernandes, P., Immobilization of inulinase for sucrose hydrolysis. Food Chemistry, 91, 517 (2005).

Cazetta, M. L., Martins, P. M. M, Monti, R. and Contiero, J., Yacon, (Polymia sanchifolia) extract as a substrate to produce inulinase by Kluyveromyces marxianus var. bulgaricus. Journal of Food Engineering, 66, 301 (2005).

Ettalibi, M. and Baratti, J. C., Sucrose hydrolysis by the thermostable immobilized inulinases from Aspergillus ficum. Enzyme and Microbial Technology, 28, 596 (2001).

Gao, S., Wang, Y., Luo, G. and Dai, Y., Immobilization of lipase on methyl-modified silica aerogels by physical adsorption. Bioresource Technology, 100, 996 (2009).

Gemeiner, P., Enzyme Engineering: Immobilized Biosystems. Ellis Horwood, New York (1992)

Goosen C., Van Der Maarel, M. J. E. C. and Dijkhuizen, L., Exo-inulinase of Aspergillus niger N402: a hydrolytic enzyme with significant transfructosylating activity. Biocatalysis and Biotrasnformation, 26, 49 (2008).

Huang, X. J., Yu, A. G. and Xu, Z. K., Covalent immobilization of lipase from Candida rugosa onto poly(acrylonitrile-co-2-hydroxyethyl methacrylate) electrospun fibrous membranes for potential bioreactor application. Bioresource Technology, 99, 5459 (2008).

Klibanov, A. M., Improving enzymes by using them in organic solvents. Nature, 409, 241 (2001).

Kumari, A., Mahapatra, P., Kumar, G. V. and Banerjee, R., Comparative study of thermostability and ester synthesis ability of free and immobilized lipases on cross linked silica gel. Bioprocess and Biosystems Engineering 31, 291 (2008). 
Mazutti, M., Ceni, G., Di Luccio, M. and Treichel, H., Production of inulinase by solid-state fermentation: effect of process parameters on production and preliminary characterization of enzyme preparations. Bioprocess and Biosystems Engineering, 30, 297 (2007).

Miller, G. L., Use of dinitrosalisylic acid reagent for determination of reducing sugar. Analytical Chemistry, 31, 426 (1959).

Ogino, H., Gemba, Y., Yutori, Y., Doukyu, N., Ishimi, K. and Ishikawa, H., Stabilities and conformational transictions of various proteases in the presence of an organic solvent. Biotechnology Progress, 23, 155 (2007).

Rahman, R. N. Z. R. A., Geok, L. P., Basri, M. and Salleh, A. B., An organic solvent-stable alkaline protease from Pseudomonas aeruginosa strain K: enzyme purification and characterization. Enzyme and Microbial Technology, 39, 1484 (2006).

Risso, F. A. V., Mazutti, M. A., Costa, F., Maugeri, F. and Rodrigues, M. I., Comparison between Systems for Synthesis of Fructooligosaccharides from Sucrose Using Free Inulinase from Kluyveromyces marxianus NRRL Y-7571.
Food and Bioprocess Technology, DOI: 10.1007/s11947-009-0272-1 (2009).

Santos, A. M. P., Oliveira, M. G. and Maugeri, F., Modeling thermal stability and activity of free and immobilized enzymes as a novel tool for enzyme reactor design. Bioresource Technology, 98, 3142 (2007).

Silva-Santisteban, B. O. Y. and Maugeri, F., Agitation, aeration and shear stress as key factors in inulinase production by Kluyveromyces marxianus. Enzyme and Microbial Technology, 36, 717 (2005).

Singh, R. S., Dhaliwal, R. and Puri, M., Production of high fructose syrup from Asparagus inulin using immobilized exoinulinase from Kluyveromyces marxianus YS-1. Journal of Industrial Microbiology and Biotechnology, 34, 649 (2007).

Treichel, H., Mazutti, M. A., Maugeri, F. and Rodrigues, M. I., Use of a sequential strategy of experimental design to optimize the inulinase production in a batch bioreactor. Bioprocess and Biosystems Engineering, 32, 425 (2009).

Wang, Q., Yang, Z., Wang, L., Ma, M., and Xu, B., Molecular hydrogel-immobilized enzymes exhibit superactivity and high stability in organic solvents. Chemical Communications, 1032 (2007). 